\title{
The influence of the activity of street vendors on zone utilization patterns and circulation patterns in Tegallega Park, Bandung, Indonesia Subtitle: Human Centered and Social Interactions, Community Resilience and Well-Being
}

\author{
Irwan Sudarisman ${ }^{1}{ }^{*}$ Muhizam Mustafa ${ }^{2}$, Mohd Hafizal Bin Mohd Isa ${ }^{3}$ \\ ${ }^{1}$ Universiti Sains Malaysia, Malaysia \& Telkom University, Indonesia \\ ${ }^{2}$ Universiti Sains Malaysia, Malaysia \\ ${ }^{3}$ Universiti Sains Malaysia, Malaysia \\ *Corresponding author.Email: irwansudarisman@telkomuniversity.ac.id
}

\begin{abstract}
Street vendors carrying out commercial activities in public spaces are a common phenomenon in big cities in Indonesia. Various responds have been made by the city government, starting from arrangement, moving to eviction. Arrangement is considered to be the most successful respond. One form of arrangement is to provide a suitable space for the activities. Knowledge and understanding of the effect of activities on zone utilization patterns and circulation patterns are very important in appropriate spatial planning. Tegallega Park as a public space in the city of Bandung experiences this phenomenon and is used as an object of study. The research method used is qualitative through field observations and mapping. Observations were made on the activities of traders and residents, while the mapping was carried out on types of traders, types of activities, zones and circulation, both pedestrians and motorized vehicles. The results of the study found that the presence of traders' activities caused changes in zone use, the formation of new zones, increased diversity of zones but the dissertation reduced the area of the existing zones, changes in circulation patterns of motorized vehicles and pedestrians which were marked by reduced accessibility of motorized vehicles while increased pedestrian accessibility. Based on the results of the study it can be concluded that a redesign of the park is necessary, by providing a more diverse zone but in a smaller area and reducing vehicle circulation and increasing pedestrian circulation. The author realizes that this research is not perfect, considering that there are other components that have not been studied, including the type of street vendors business media and the quality of the existing space in the park. These components can be used as objects of research in the future.
\end{abstract}

Keywords: Public Space, Street Vendors, Activity, Zone, and Circulation.

\section{INTRODUCTION}

Public spaces of cities used for a variety of often overlapping functional and symbolic purposes. Public spaces have been multi-purpose accessible spaces. These spaces are considered public and have concerned the people as a whole, being open or available to them and being used or shared by all members of a community [1].

The common features expected from all public spaces are: provide opportunities for social life, include various activities, convenient to use by access and linkage, and has unique identity with image. Public spaces should play an important role in the outdoor activities of urban residents and contribute to strengthening social interactions between citizens (Oliveira and Andrade, 2007) [2].

One form of public space in the city is a city park. City parks are open to be enjoyed and used by all urban communities (everyone has the same rights). City parks have various functions, namely as a place for nature conservation, relieving stress by relaxing 
and playing, exercising and socializing. City parks with various uses and benefits become very important for urban people.

Currently, many urban parks located in big cities in Indonesia are experiencing various problems such as irregularity, cleanliness and a decrease in the physical quality of the park (beauty). One of the reasons for this is the change in the function of the zone within the park that is not in accordance with the original designation of the zone. The change in the function of the zone is caused by the use of public spaces, one of which is city parks, as a place to run businesses from the informal sector.

Since the economic crisis in Indonesia in 1998, many people have lost their livelihoods and have been forced to move to the informal sector to earn income. In addition, the high flow of urbanization and disproportionate to the availability of employment opportunities has also led to the proliferation of this informal sector. Many informal sectors use the city's public space to run their business.

Street trading is a form of urban informality, which can be traced back to the conception of "informal sector" coined by Keith Hart in the 1970s to elaborate on informal/formal income opportunities [3]. Existence of such occupational sectors offers employment opportunities and aids the economic functioning of the cities in the less-developed countries of the world [4].

Hawkers cause problems of hygiene and sanitary control; they cause congestion to all parts of the urban area. In the eyes of many city administrators, this "problem" aspect of hawker operations greatly outweighs the advantages that hawkers provide [4].

The hawkers were enumerated by major categories of goods sold (namely, unprocessed food such as vegetables; semi processed and processed food like coconut juice and cooked food; non-food durables that consisted of goods bought occasionally to last a long time such as records and mats; non-food nondurables intended for rapid consumption such as toothpaste, medicine, etc; textiles and clothing; and finally, services such as barbers, shoe menders, etc.) [4].

Hawkers tend to concentrate in areas of high population density at nodes of transportation transfer, or adjacent to activities such as entertainment complexes, public markets, and commercial enterprises where they can benefit from product complementarity and mutual customer attraction [4].

Various actions were taken by the city government to overcome problems related to street vendors in the form of evictions, relocation of locations to rearrangement of the merchant's business area. Restructuring efforts are the most successful and accepted by street vendors. Meanwhile, relocation efforts often cause the business of traders to experience a decrease in income or even to bankruptcy.

Rearrangement of the place of business of street vendors in public spaces, especially parks, requires careful planning of zones by considering the needs of traders and the impact of the presence of merchant activities in public spaces. The results of this study are expected to be a basis for consideration for parties involved in planning and designing public spaces, especially city parks, in order to create parks that can accommodate the needs of the community, including street vendors, properly.

\section{CONTENTS}

This study contains an analysis of the activities of street vendors, activities of park users, and activities around the park area to see the relationship between these components and their influence on the utilization of the existing zone and circulation patterns (pedestrians and vehicles) in the Tegallega park. Analysis of merchant activities is carried out based on the type of business carried out by street vendors. User activity analysis is carried out based on the type of activity. While the analysis of the area around the park is carried out based on the types of activities that take place in each of these areas.

The research method used is qualitative through field observations and mapping. Observations were made on the activities of traders and residents, while the mapping was carried out on types of traders, types of activities, zones and circulation, both pedestrians and motorized vehicles. The presentation of research results is carried out in the form of analytical descriptive and field condition maps.

\section{FINDINGS}

Tegallega Park is surrounded by various activity areas. The eastern area is adjacent to residential activity areas, government offices (Hubdam III Siliwangi) and Education (SMP Negeri 11). The western area is adjacent to the trading activity area (Astana Anyar secondhand flea market and shops), residential areas, education (Muhammadiyah Islamic boarding school) and the Tegallega terminal. The area to the north is adjacent to the residential activity area and shops. The southern area is adjacent to the area for government office activities, museums (Sri Baduga) 
and residential areas. Tegallega Park has an area of 16 hectares and various sports facilities, such as swimming pools, soccer and running fields, basketball courts, jogging tracks, skate board facilities, as well as a plaza that can be used as a place for gymnastics and martial arts training. Tegallega Park also has other facilities such as a green area (urban forest), a lantern and dinosaur plaza as entertainment facilities, an amphitheatre, a Bandung Lautan Api plaza and monument as a place to hold ceremonial events, a plaza for performances, a museum, and a centre for selling ornamental plants. In addition, Tegallega Park has supporting facilities such as a mosque, public toilets and a motorized vehicle parking area. The variety of facilities owned causes a variety of active (sports and playing) and passive (relaxing and socializing) activities for visitors to do in the park. The facilities scattered in every area of the park cause the emergence of the centre points of crowds and human movement from one point to another. Tegallega Park is surrounded by roads that connect various areas, namely the city entrance gate, the city centre and the suburbs (settlements). To the east and west, Tegallega Park is bordered by Mohammad Toha and Otto Iskandar Dinata roads which connect the suburbs (settlements) with the city centre. To the south, Tegallega Park is bordered by Jalan BKR (the main street in Bandung) which connects the city gate area with the city centre. These streets have high movement, especially in the morning and evening. The position of the Tegallega Park which is adjacent to various areas with diverse activities and high density (population settlements), has a variety of facilities that cause the emergence of points of high density and human movement in the park, and is surrounded by city roads with high movement which is an attraction for tourists. street vendors for activities both in and around Tegallega Park.

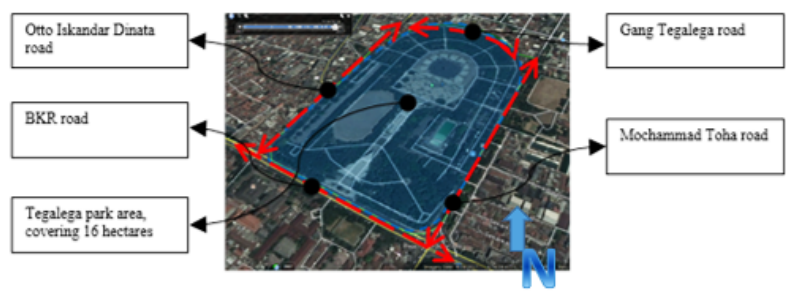

Figure 1 Tegallega Park aerial view.

Street vendors mostly congregate in the East and West areas of the park. The gathering of street vendors in the area is due to several factors, namely access to the park for pedestrians and motorized vehicles, as well as motorized vehicle parking facilities located in the area. East area adjacent to Mohammad Toha road. This road is a route that many cities' residents pass, especially in the morning, to be active in the downtown area. Street vendors gather in the East area from morning to noon. While the western area is adjacent to Otto Iskandar Dinata road. This road is a route that many city dwellers take, especially in the afternoon and evening, to return to residential areas on the outskirts of the city. Street vendors gather in the West area in the afternoon until the evening. The high movement of people and vehicles in the East and West areas is an attraction for street vendors to carry out their activities in these areas. In the East area there are various sports facilities in the form of swimming pools, basketball courts, therapy facilities and a plaza that can be used for gymnastics, martial arts and others. Facilities in the form of a mosque, public toilets and a centre for selling ornamental plants are also located in the East area. While in the park area to the west there are sports facilities in the form of soccer fields and running fields, as well as large parking facilities that can be used for various functions such as gymnastics, music performances and night markets. Various public facilities located in the East and West areas cause many park users to gather in these areas (crowded points). The high density is an attraction for street vendors to carry out their activities in the area.

While on the north side there is no access to enter the park and the south side is part of the park which is prohibited by the city government from being used as a place for street vendors. This is indicated by the use of a wire fence as a barrier and the presence of city order officers (Satpol PP). This condition causes the two sides of the park not to have as many street vendors as the East and West sides.

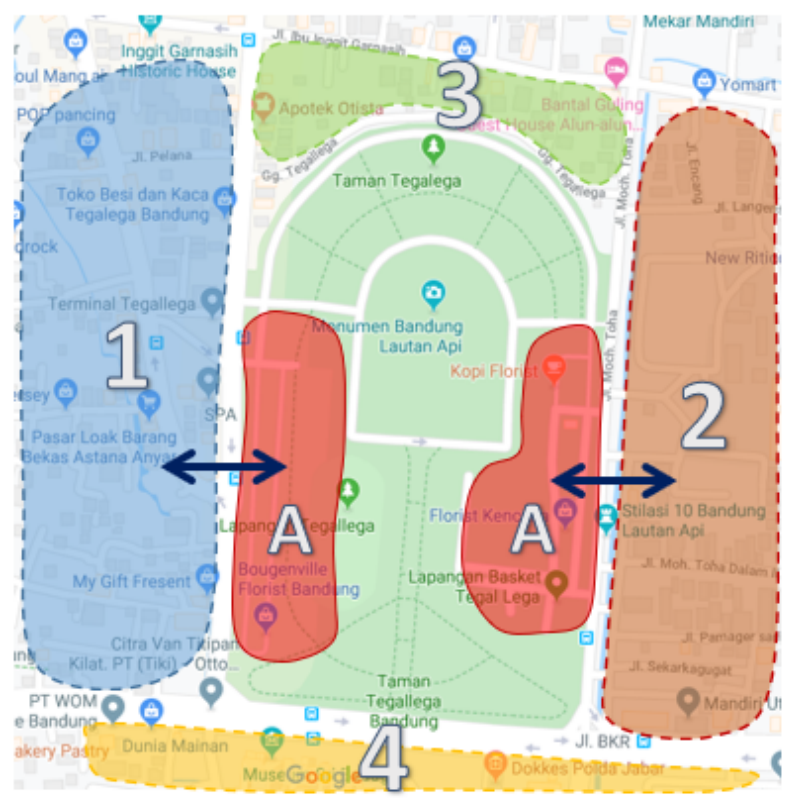




\section{LEGEND}

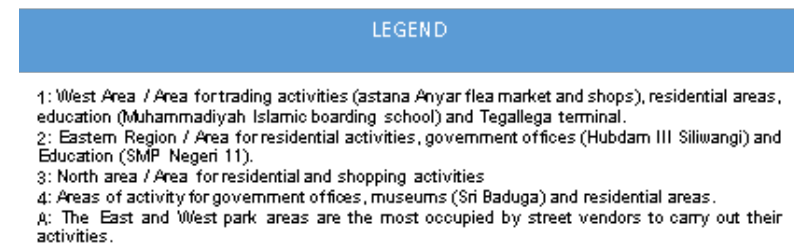

Figure 2 Street vendor activity area

Tegallega Park is divided into several zones, namely the Bandung Lautan Api historical monument zone, plaza / multifunction zone, green zone (urban forest), commercial zone, sports zone, tourist zone, and support zone. These zones are used to accommodate various visitor activities according to the function of each zone. The historical monument zone of Bandung Lautan Api (monument facilities, museums and plazas) is used for commemorative and educational activities. The plaza / multifunction zone (amphitheater and plaza facilities) is used for a variety of performing arts activities, competitions, sports (gymnastics), socializing, relaxing and playing. The green zone / urban forest (plant facilities (trees) and water catchment) is used for leisure activities and walks. The commercial zone (ornamental plant market facility) is used to sell various ornamental plants. Sports zones (swimming pool facilities, skate board, soccer and running fields, and basketball courts) are used for sports activities. The tourist zone (lantern and dinosaur garden facilities) is used for relaxing, playing and socializing activities. Supporting zones (mosque facilities, public toilets and parking) are used for worship activities, self-cleaning and parking vehicles. Circulation zones (pedestrian and vehicle lane facilities) are used for human and vehicle movement activities. When street vendors are not active in the park, these zones are used according to their function. This causes order, beauty and cleanliness in the garden to be maintained.
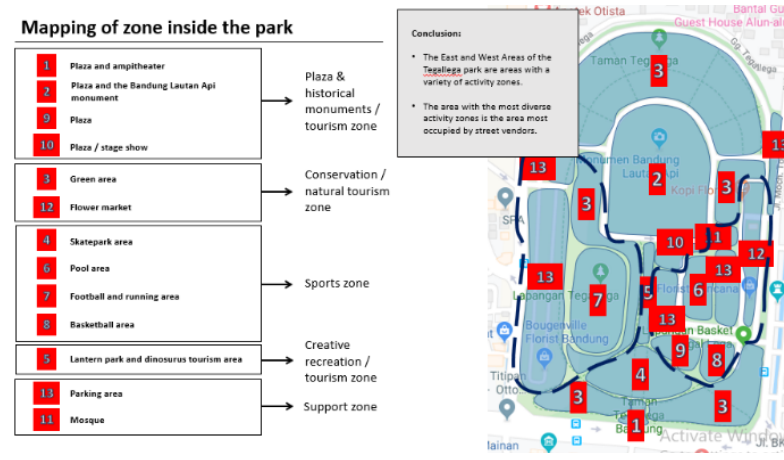

Figure 3 Existing zone

The presence of street vendors in the Tegallega park causes a change in the function of the existing zones, one of which is to facilitate the business activities of traders. Street vendors selling raw and semi-finished materials (food) tend to occupy the sidewalk area adjacent to Mohammad Toha Street and the park entrance area on the east side of the park (using the pedestrian area and vehicle lanes). In addition, many street vendors selling non-food items (household necessities) also occupy these two areas (using pedestrian areas and vehicle lanes). They occupy the east side to be close to potential consumers who come from residential areas. Street vendors selling non-food items (fashion) tend to occupy the sidewalk area adjacent to Mohammad Toha street, the park entrance area on the East and West sides of the park (using pedestrian paths and vehicle lanes), as well as support zones (using parking facilities). on the west side. They occupy the east side to be close to potential consumers who come from residential areas. Meanwhile, they occupy the west side which is adjacent to the commercial area (shops that sell one of the fashion items) so that they are close to potential consumers who are shopping in the area. Street vendors who provide service services (borrowing sports equipment, children's play facilities and mats, as well as alternative medicine) tend to occupy green zones / urban forests (using pedestrian paths, vehicle lanes and plant areas / trees) which are on the West and North sides park. They occupy the green zone to be close to potential customers who are doing leisure activities and walking around. In addition, they occupy a monument zone (plaza facility) in the center of the park. They occupy the monument zone so that they are close to potential consumers who are doing activities to visit the monument and take a walk. Street vendors selling ready-to-eat food occupy almost all parts of the park (Central, East, West, North and South). They occupy the East side (the sidewalk area, the edge of the vehicle lane and the entrance area, as well as the support zone / parking area and plaza) to be closer to potential consumers who come from residential areas, offices and education (schools), park visitors who are exercising, as well as motorists who pass through the Mohammad Toha road from morning to noon. They occupy the West side (the sidewalk area, the edge of the vehicle lane and the entrance area, as well as the support zone / parking area and green zone) to be closer to potential consumers who are shopping in the commercial area (shops), visitors who are exercising, relaxing and walking -roads, as well as motorists who pass through Otto Iskandar Dinata road during the day and night. They occupy the North side (pedestrian area and plants) to be closer to potential customers who are relaxing and strolling in the green zone. They occupy the south side (plaza zone, tourism and sports) to be closer to potential customers who are relaxing, playing, socializing and exercising in the 
plaza area, amphitheater, lantern and dinosaur park, as well as sports facilities (skate board). In addition, they also occupy the center of the park (monument and plaza zones) to be close to potential customers who are visiting monuments and museums, exercising, relaxing and socializing in the plaza area.

The presence of street vendors also causes the emergence of various activities. These activities arise as a result of the interaction of traders with other park users, resulting in changes in the function of the existing zones. The monument zone that is used for commemoration and educational activities has changed its function as a place for business, exercise, play, and eating/drinking. The plaza/multifunctional zone that is used for performing arts activities, competitions, sports (gymnastics), socializing, relaxing and playing increases its function as a place of business and eating/drinking. The green zone / urban forest which is used for relaxing and walking activities increases its function as a place to exercise, play, socialize, do business, and eat / drink. The tourist zone which is used for relaxing, playing and socializing activities increases its function as a place for business activities and eating/drinking. The supporting zone used for vehicle parking is partially changed to a place for business activities, shopping and eating/drinking. Circulation zone used for movement activities Partly changed for business activities, shopping and eating/drinking. The presence of new activities in the existing zone causes a change in part of the existing zone area into a new zone. As a result, the types of zones in the park are more diverse but have a smaller area.
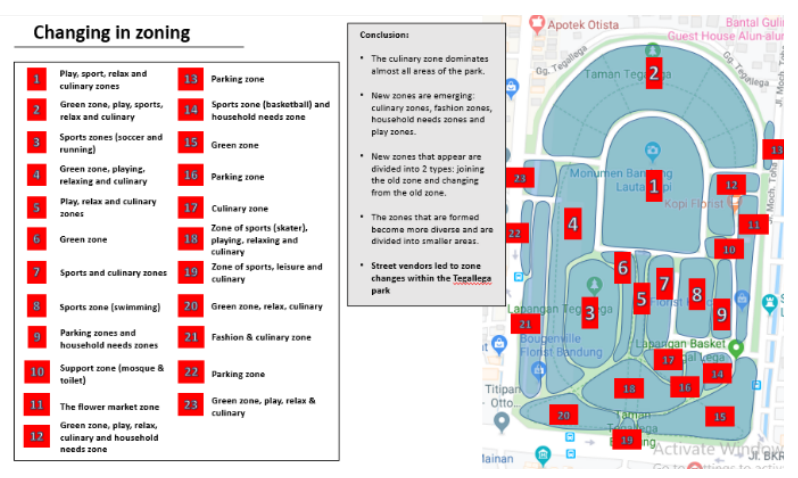

Figure 4 Zone change

Changes in the function of some areas of the circulation zone cause changes in accessibility. Business activities, shopping, eating / drinking from street vendors and other park users who use some of the circulation zone area (vehicle lane facilities) cause vehicle access to become narrower. Vehicles cannot access vehicle lanes around the monument zone and some supporting zones (parking facilities).
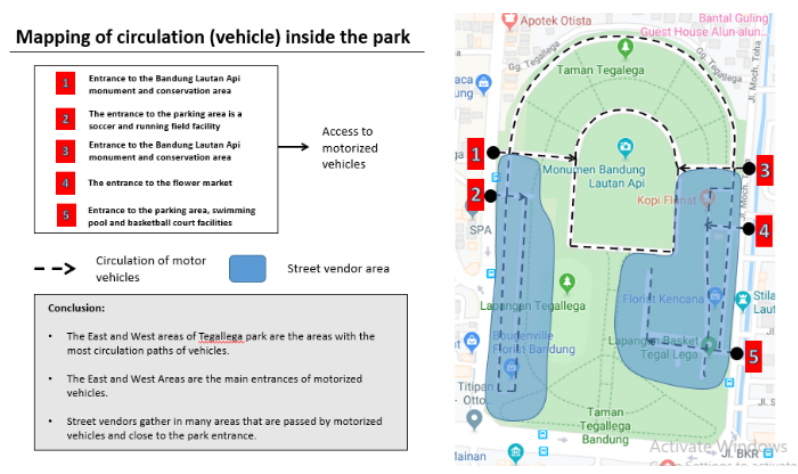

Figure 5 Existing vehicle circulation

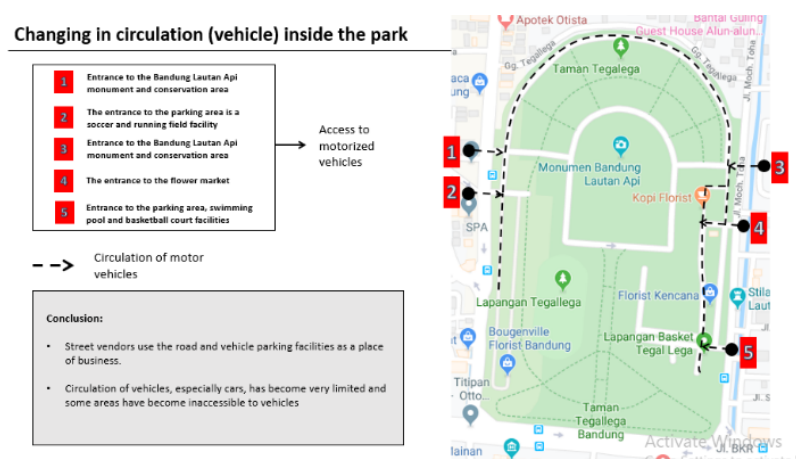

Figure 6 Vehicle circulation change

Meanwhile, access for pedestrians has become wider because some of the vehicle lanes have changed their functions to become places for walking. The vehicle lanes that have been converted into walking areas are located around the green zone on the North side and in the support zone (parking facilities) on the West side.
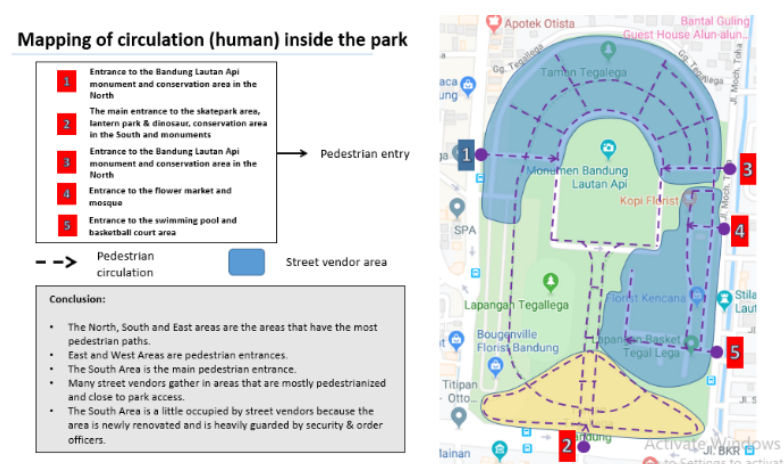

Figure 7 Existing pedestrian circulation 

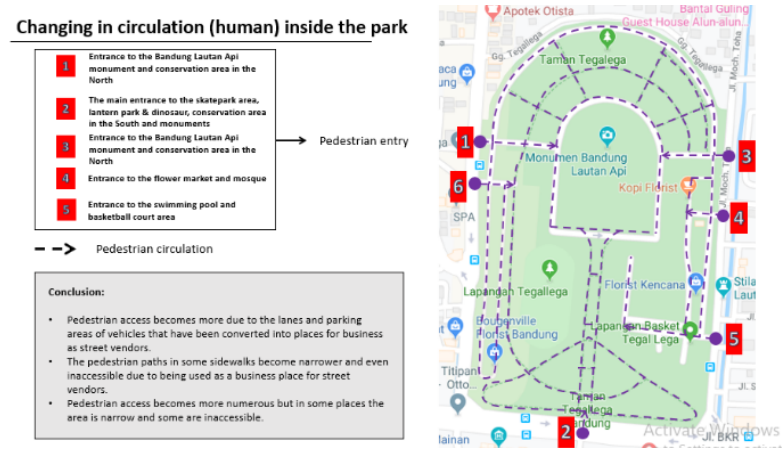

Figure 8 Pedestrian circulation change

\section{CONCLUSIONS}

Street vendors who carry out activities in the park cause the emergence of shopping zones (household needs, both raw food ingredients, semi-finished food, and non-food items) and culinary zones. The location of this shopping and culinary zone is determined by several factors, namely access to the park, activities in the area around the park, activities in the park, movement of people and vehicles, as well as the needs of potential consumers both in and around the Tegallega park.

The interaction between street vendors and park users causes the emergence of other activities. These activities are shopping, eating/drinking, exercising, playing and socializing. Shopping activities arise as a form of interaction with traders of raw and semifinished foodstuffs, as well as non-food goods. Eating/drinking activities emerged as a form of interaction with ready-to-eat food vendors. Sports activities appear as a form of interaction with traders who rent sports equipment. Play activities appear as a form of interaction with traders who rent out children's play equipment. Meanwhile, socializing activities appear as a form of interaction with traders who rent out sitting equipment (mats).

The activities of traders and the activities of park users as a form of interaction with traders that take place in existing zones within the park cause changes to these zones. The change that occurs is that one existing zone can be divided into several different zones with a smaller area. In addition, changes also occurred in the functions of the existing zone which became more diverse (Most of them did not eliminate their initial functions, but some of them removed their original functions (monument zone and circulation zone)).

Changes in the function of the existing zone that are not in accordance with its original function can cause problems of cleanliness and beauty (damage to the physical condition of the existing zone) thus affecting the comfort of park users. Through the results of this study, it is hoped that in the design of city parks both renovation and new zones can be formed that are suitable for the activities of street vendors and other park users so that problems can be avoided.

\section{REFERENCES}

[1] A. Madanipour. Public and Private Spaces of the City. London: Routledge; 2003.

[2] E.K. Karaçor, Public vs. Private: The Evaluation of Different Space Types in Terms of Publicness Dimension, in : European Journal of Sustainable Development, vol.5(3), pp.51-58, 2016.

[3] H. Kamalipour, N. Peimani, Negotiating Space and Visibility: Forms of Informality in Public Space, in : Sustainability,2019.

[4] T.G. McGee, Y.M. Yeung, Hawkers in Southeast Asian Cities: Planning for the Bazaar Economy, in : Ottawa: International Development Research Center, 1977. 